Amosa Komeńskiego, który bardzo wiele zawdzięczał profesorom Gdańskiego Gimnazjum Akademickiego w XVII wieku, otworzył prof. Lech Mokrzecki. Omówił on najważniejsze zasługi profesorów gdańskich w formowaniu się poglądów dydaktycznych czeskiego pedagoga.

Konferencję uświetnił między innymi również występ chóru uczelnianego, który swe powstanie i wieloletnie kierownictwo zawdzięcza prof. Lechowi Mokrzeckiemu.

\title{
Adam Fijatkowski
}

(sekretarz THE)

\section{Rola historii wychowania w Polsce na początku XXI wieku}

12 listopada 2009 roku pod patronatem THE odbyło się w Warszawie spotkanie historyków wychowania $\mathrm{z}$ całego kraju. Wzięło w nim udział ponad 30 osób - w tym Zarząd Główny THE. Inicjatorką i organizatorką spotkania, a jednocześnie moderatorką wielogodzinnej dysputy była prof. Kalina Bartnicka. Ważny głos w dyspucie zajął między innymi prof. Józef Miąso i prof. Karol Poznański.

Celem spotkania była rzeczywista i krytyczna dyskusja. Służyła ona wymianie doświadczeń na temat obecnej roli historii wychowania w Polsce, a także wyzwań i zadań, jakie stoją w związku z tym przed naszym środowiskiem. Zebrani żywo dyskutowali na temat obecności historyków wychowania w licznych organizacjach i inicjatywach naukowych, w konferencjach krajowych i zagranicznych, projektach badawczych itp. Spotkanie służyło także integracji naszego środowiska, wymianie spostrzeżeń na temat najnowszych publikacji naukowych bliskich naszej dziedzinie, kierunków prowadzonych badań itp.

Zebrani zgodzili się, że integracja i dalsze ożywienie współpracy naszego środowiska jest rzeczą bardzo istotną i że ważną rolę winno tu odegrać również THE, co prof. Wiesław Jamrożek, Prezes THE i inni członkowie Zarządu Głównego przyjęli ze zrozumieniem i pełną aprobatą. 